\title{
Bimetallic aluminum alkyl and iodide complexes stabilized by a bulky bis-guanidinate ligand
}

\author{
THOTA PEDDARAO, ASHIM BAISHYA, SURAJ KUMAR HOTA and \\ SHARANAPPA NEMBENNA*(1)
}

School of Chemical Sciences, National Institute of Science Education and Research (NISER), Homi Bhaba National Institute, Bhubaneswar, Odisha 752 050, India

E-mail: snembenna@niser.ac.in

MS received 2 April 2018; revised 13 May 2018; accepted 14 May 2018; published online 12 July 2018

\begin{abstract}
A series of bulky bis-guanidine ligands such as $\mathrm{L}^{1}(2 \mathrm{H}), \mathrm{L}^{2}(2 \mathrm{H})$ and $\mathrm{L}^{3}(2 \mathrm{H})$, where $\mathrm{L}=$ $\{\text { ArNCNAr }\}_{2}\left\{\mu-\mathrm{N}\left(\mathrm{C}_{2} \mathrm{H}_{4}\right)_{2} \mathrm{~N}\right\}$, for $\mathrm{L}^{1}(2 \mathrm{H})\left(\mathrm{Ar}=2,6-\mathrm{Me}_{2}-\mathrm{C}_{6} \mathrm{H}_{3}\right), \mathrm{L}^{2}(2 \mathrm{H})\left(\mathrm{Ar}=2,4,6-\mathrm{Me}_{3}-\mathrm{C}_{6} \mathrm{H}_{2}\right)$ and $\left(\mathrm{L}^{3}(2 \mathrm{H})\right)\left(\mathrm{Ar}=2,6{ }^{i}{ }^{i} \mathrm{Pr}_{2}-\mathrm{C}_{6} \mathrm{H}_{3}\right)$ have been utilized to synthesize four-membered dinuclear aluminum heterocycles. Deprotonation of $\mathrm{L}^{1-3}(2 \mathrm{H})$ (1.0 equiv.) upon treatment with trimethyl aluminum (2.1 equiv.) in toluene led to the formation of bimetallic aluminum alkyls: $\left[\mathrm{L}^{1}\left(\mathrm{AlMe}_{2}\right)_{2}\right](\mathbf{1}),\left[\mathrm{L}^{2}\left(\mathrm{AlMe}_{2}\right)_{2}\right](\mathbf{2})$ and $\left[\mathrm{L}^{3}\left(\mathrm{AlMe}_{2}\right)_{2}\right](\mathbf{3})$. Aluminum halide complex i.e., $\left[\mathrm{L}^{3}\left(\mathrm{AlI}_{2}\right)_{2}\right](\mathbf{4})$ was obtained by the reaction of compound 3 with four equivalents of molecular iodine in toluene at $80^{\circ} \mathrm{C}$, in which alkyl-halide exchange occurred. All the compounds (1-4) were confirmed by multinuclear $\left({ }^{1} \mathrm{H}\right.$ and $\left.{ }^{13} \mathrm{C}\right)$ magnetic resonance spectroscopy. Furthermore, compounds 2-4 were confirmed by single crystal X-ray structural analysis. All the compounds 1-4 display the expected number of signals in the ${ }^{1} \mathrm{H}$ and ${ }^{13} \mathrm{C}$ NMR spectra and are consistent with their compositions. The solid state structures of 1-4 reveal that each aluminum center is bonded to the monoanionic guanidinate ligand in $N, N^{\prime}$-chelated fashion and the other two sites are occupied by alkyl or halide ligands, resulting in a distorted tetrahedral geometry.
\end{abstract}

Keywords. Aluminum; guanidine; group 13 metal; main group metal; $N, N^{\prime}$-donor ligand; organoaluminum complex.

\section{Introduction}

Since the synthesis of first transition metal guanidinate complex by Lappert and coworkers ${ }^{1}$ in 1970 , coordination chemistry of anionic guanidinates has been studied significantly, resulting in various complexes incorporating elements from all blocks of the periodic table. ${ }^{2-4}$ Moreover, tetra-substituted bulky guanidinate anions are ideal precursors for the isolation of low valent and/or low oxidation state metal complexes, because these can give steric and/or electronic protection. ${ }^{5}$

To date, several examples of mononuclear guanidinato aluminum complexes, including aluminum alkyls and halides are known in the literature. ${ }^{6-13}$ Recent reports suggest that dinuclear aluminum complexes

\footnotetext{
*For correspondence
}

are more important precursors for ring opening polymerization (ROP) of cyclic esters (e.g., lactide and $\varepsilon$-caprolactone), cyclic ethers (e.g., cyclohexne oxide $(\mathrm{CHO})$ and propylene oxide (PO)) than their monometallic counterparts. ${ }^{14-16}$ Despite the prominent role of cooperative effect between two aluminum centers, synthesis and catalytic application of well-characterized dinuclear aluminum complexes remain scarce. To the best our knowledge, there are no reports on dinuclear guanidinates of aluminum complexes. Therefore, we targeted to synthesize dinuclear aluminum complexes by utilizing bi-nucleating ligands. ${ }^{17}$

The application of molecular compounds of aluminum or aluminum-based reagents in catalysis is an attractive area of recent research interest. ${ }^{18}$ This is due to large abundance, low cost and low toxicity of aluminum. Recently, it has been demonstrated that aluminum based molecular compounds can be utilized as catalysts for 
various organic transformations, including hydroboration of carbonyl compounds, hydroboration of olefins and alkynes, cynosilylation, etc. ${ }^{19-23}$

Herein, we report the synthesis and characterization of bi-nucleating bis-guanidine supported dinuclear aluminum(III) alkyl and halide complexes.

\section{Experimental}

\subsection{General procedures}

All the reactions dealing with air- and moisture-sensitive compounds were carried out in standard Schlenk line and Glove-box filled with nitrogen gas, unless otherwise noted. The precursors were prepared by following literature procedures. ${ }^{24,25}$ Anhydrous solvents toluene and $n$-hexane were collected from mBRAUN solvent purification system and used as such. Deuterated benzene $\left(\mathrm{C}_{6} \mathrm{D}_{6}\right)$ was dried over a sodium mirror in vacuum prior to use. Deuterated chloroform $\left(\mathrm{CDCl}_{3}\right)$ was dried over $\mathrm{MgSO}_{4}$ and stored on molecular sieves. NMR spectra $\left\{{ }^{1} \mathrm{H}(400 \mathrm{MHz})\right.$, and ${ }^{13} \mathrm{C}(101 \mathrm{MHz})$ were recorded on Bruker AV $400 \mathrm{MHz}$ instrument. The chemical shift values are reported in parts per million (ppm) and are referenced to the residual solvent $\left(7.16\right.$ and 7.26 for ${ }^{1} \mathrm{H}$; 128.09 and 77.16 for ${ }^{13} \mathrm{C}$, in $\mathrm{C}_{6} \mathrm{D}_{6}, \mathrm{CDCl}_{3}$, respectively). Melting points were recorded on digital melting point apparatus and are uncorrected.

\subsection{Crystallographic information}

Crystals of suitable quality for X-ray diffraction studies of compounds 2-4 were withdrawn from Schlenk flask under the atmosphere of nitrogen and covered with a layer of paraffin oil. A good quality single crystal was selected, mounted on a glass fiber, and then placed quickly in a stream of liquid nitrogen on an X-ray diffractometer. The X-ray data were collected on a Bruker 4-circle Kappa APEX-II diffractometer equipped with a CCD detector using graphite monochromated Mo-K $\alpha$ radiation $(\lambda=0.71073 \AA)$ at $100 \mathrm{~K}$. Data collection was monitored with Apex II software, and preprocessing was done with SADABS integrated with Apex II. Using Olex $2,{ }^{26}$ the structures were solved with the ShelXT structure solution program using Direct methods and refined with the ShelXL ${ }^{27,28}$ refinement package using Least Squares minimisation. All non-hydrogen atoms were refined anisotropically. Hydrogen atom positions were calculated geometrically and refined using the riding model.

\subsection{Synthesis and characterization of compounds 1-4}

2.3a Synthesis of compound 1: To a stirred solution of $\mathrm{L}^{1}(2 \mathrm{H})(0.3 \mathrm{~g}, 0.511 \mathrm{mmol}, 1.0$ equiv.) in toluene $(\sim 10 \mathrm{~mL})$, trimethyl aluminum $(2.0 \mathrm{M}$ in toluene, $0.54 \mathrm{~mL}$ and $1.073 \mathrm{mmol}, 2.1$ equiv.) was added at $-78{ }^{\circ} \mathrm{C}$. Then, the resulting reaction mixture was slowly warmed to room temperature and continued stirring for $15 \mathrm{~h}$. The volatiles were removed under reduced pressure. The residue was dried in vacuo to give the product, which was recrystallized from toluene solution at room temperature to give colorless crystals of complex 1. (Yield: $0.221 \mathrm{~g}, 0.316 \mathrm{mmol}, 62 \%$ ). M.p.: 185-190 ${ }^{\circ} \mathrm{C} ;{ }^{1} \mathrm{H}$ NMR $\left(400 \mathrm{MHz}, \mathrm{C}_{6} \mathrm{D}_{6}, 25{ }^{\circ} \mathrm{C}\right): \delta-0.34$ (s, 12H, $\left.\mathrm{Al}\left(\mathrm{CH}_{3}\right)_{2}\right), 2.13$ (s, 24H), $2.35\left(\mathrm{~s}, 8 \mathrm{H}, \mathrm{N}\left(\mathrm{CH}_{2}\right)_{2} \mathrm{~N}\right)$, $6.82(\mathrm{~s}, 12 \mathrm{H}, \mathrm{Ar} H) .{ }^{13} \mathrm{C}$ NMR $\left(101 \mathrm{MHz}, \mathrm{C}_{6} \mathrm{D}_{6}, 25^{\circ} \mathrm{C}\right): \delta-$ $9.2 \mathrm{Al}\left(\mathrm{CH}_{3}\right)_{2}, 18.9\left(\mathrm{CH}_{3}\right), 44.8\left(\mathrm{~N}\left(\mathrm{CH}_{2}\right)_{2} \mathrm{~N}\right), 124.8(\mathrm{ArC})$, $128.9(\mathrm{ArC}), 133.1(\mathrm{ArC}), 141.6(\mathrm{ArC}), 163.1\left(\mathrm{~N}_{3} C\right)$.

2.3b Synthesis of compound 2: To a stirred solution of $\mathrm{L}^{2}(2 \mathrm{H})(0.3 \mathrm{~g}, 0.466 \mathrm{mmol}, 1.0$ equiv. $)$ in toluene $(\sim 10 \mathrm{~mL})$, trimethyl aluminum $(2.0 \mathrm{M}$ in toluene, $0.49 \mathrm{~mL}$, and 0.979 mmol, 2.1 equiv.) was added at $-78{ }^{\circ} \mathrm{C}$. Then the resulting reaction mixture was slowly warmed to room temperature and continued stirring for $15 \mathrm{~h}$. The volatiles were removed under reduced pressure. The residue was dried in vacuo to give the product, which was recrystallized from toluene solution at room temperature to give colorless crystals of complex 2. (Yield: $0.211 \mathrm{~g}, 0.28 \mathrm{mmol}, 60 \%)$. M.p.: 230-237 ${ }^{\circ} \mathrm{C} ;{ }^{1} \mathrm{H}$ NMR $\left(400 \mathrm{MHz}, \mathrm{C}_{6} \mathrm{D}_{6}, 25{ }^{\circ} \mathrm{C}\right): \delta-0.31$ $\left(\mathrm{s}, 12 \mathrm{H}, \mathrm{Al}\left(\mathrm{CH}_{3}\right)_{2}\right), 2.13\left(\mathrm{~d}, J=4.0 \mathrm{~Hz}, 36 \mathrm{H}, \mathrm{CH}_{3}\right)$, $2.44\left(\mathrm{~s}, 8 \mathrm{H},\left(\mathrm{N}\left(\mathrm{CH}_{2}\right)_{2} \mathrm{~N}\right)\right), 6.63(\mathrm{~s}, 8 \mathrm{H}, \mathrm{ArH}) .{ }^{13} \mathrm{C} \mathrm{NMR}$ $\left(101 \mathrm{MHz}, \mathrm{C}_{6} \mathrm{D}_{6}, 25{ }^{\circ} \mathrm{C}\right): \delta-9.2 \mathrm{Al}\left(\mathrm{CH}_{3}\right)_{2}, 18.8\left(\mathrm{ArCH}_{3}\right)$, $20.9\left(\mathrm{ArCH}_{3}\right), 44.8\left(\mathrm{~N}\left(\mathrm{CH}_{2}\right)_{2} \mathrm{~N}\right), 129.6(\mathrm{ArC}), 132.7(\mathrm{ArC})$, 133.6 $(\mathrm{ArC}), 139.1(\mathrm{ArC}), 163.2\left(\mathrm{~N}_{3} C\right)$.

2.3c Synthesis of compound 3: To a stirred solution of $\mathrm{L}^{3}(2 \mathrm{H})(0.3 \mathrm{~g}, 0.369 \mathrm{mmol}, 1.0$ equiv. $)$ in toluene $(\sim 10 \mathrm{~mL})$, trimethyl aluminum $(2.0 \mathrm{M}$ in toluene, $0.38 \mathrm{~mL}$, and $0.776 \mathrm{mmol}, 2.1$ equiv.) was added at room temperature. Then the resulting reaction mixture was heated to $80^{\circ} \mathrm{C}$ and continued the stirring for $24 \mathrm{~h}$. The volatiles were removed under reduced pressure. The solid residue was crystallized from toluene to obtain compound $\mathbf{3}$ as colorless crystals. (Yield: $0.2 \mathrm{~g}, 0.218 \mathrm{mmol}, 59 \%$ ). M.p.: $215-222{ }^{\circ} \mathrm{C} ;{ }^{1} \mathrm{H} \mathrm{NMR}$ $\left(400 \mathrm{MHz}, \mathrm{CDCl}_{3}, 25^{\circ} \mathrm{C}\right): \delta-0.73$ (s, $\left.12 \mathrm{H}, \mathrm{Al}\left(\mathrm{CH}_{3}\right)_{2}\right), 1.00$ $(\mathrm{d}, J=4.0 \mathrm{~Hz}, 24 \mathrm{H}), 1.10(\mathrm{~d}, J=4.0 \mathrm{~Hz}, 24 \mathrm{H}), 2.30(\mathrm{~s}, 8 \mathrm{H}$, $\left.\left(\mathrm{N}\left(\mathrm{CH}_{2}\right)_{2} \mathrm{~N}\right)\right), 3.21-3.27$ (sept, $\left.8 \mathrm{H}\right), 6.99(\mathrm{~d}, J=4.0 \mathrm{~Hz}$, $3 \mathrm{H}), 7.01(\mathrm{~s}, 5 \mathrm{H}, \operatorname{Ar} H), 7.06(\mathrm{~s}, 2 \mathrm{H}, \operatorname{Ar} H), 7.07$ (d, $J=$ $4.0 \mathrm{~Hz}, 2 \mathrm{H}, \mathrm{ArH}) .{ }^{13} \mathrm{C}$ NMR $\left(101 \mathrm{MHz}, \mathrm{CDCl}_{3}, 25^{\circ} \mathrm{C}\right)$ : $\delta-9.4 \mathrm{Al}\left(\mathrm{CH}_{3}\right)_{2}, 23.1,26.0,28.0,44.4\left(\mathrm{~N}\left(\mathrm{CH}_{2}\right)_{2} \mathrm{~N}\right)$, $123.5(\operatorname{ArC}), 125.5(\operatorname{ArC}), 138.2(\operatorname{ArC}), 144.6(\operatorname{ArC}), 162.5$ $\left(\mathrm{N}_{3} C\right)$.

2.3d Synthesis of compound 4: In a Glove box, a $\mathrm{J}$ Young valve NMR tube was charged with compound $\mathbf{3}$ $(0.030 \mathrm{~g}, 0.032 \mathrm{mmol}, 1.0$ equiv. $)$, iodine $(0.033 \mathrm{~g}$, $0.129 \mathrm{mmol}, 4.0$ equiv.), and $\mathrm{C}_{6} \mathrm{D}_{6}(0.6 \mathrm{~mL})$, and the reaction was run at $80{ }^{\circ} \mathrm{C}$ for $15 \mathrm{~h}$ in an oil bath. The progress of the reaction was monitored by ${ }^{1} \mathrm{H}$ NMR spectroscopy. Once the ${ }^{1} \mathrm{H}$ NMR spectrum confirms the complete disappearance of $\mathrm{L}^{3}(\mathrm{AlMe})_{2}$ peak, the NMR tube was kept at room temperature for 2 days, which yielded colourless crystals of compound 4. (Yield: $0.031 \mathrm{~g}, 0.0227 \mathrm{mmol}, 70 \%)$. M.p.: $270-280^{\circ} \mathrm{C} ;{ }^{1} \mathrm{H}$ NMR $\left(400 \mathrm{MHz}, \mathrm{CDCl}_{3}, 25^{\circ} \mathrm{C}\right): \delta 0.97(\mathrm{~d}, J=8.0 \mathrm{~Hz}, 24$ 


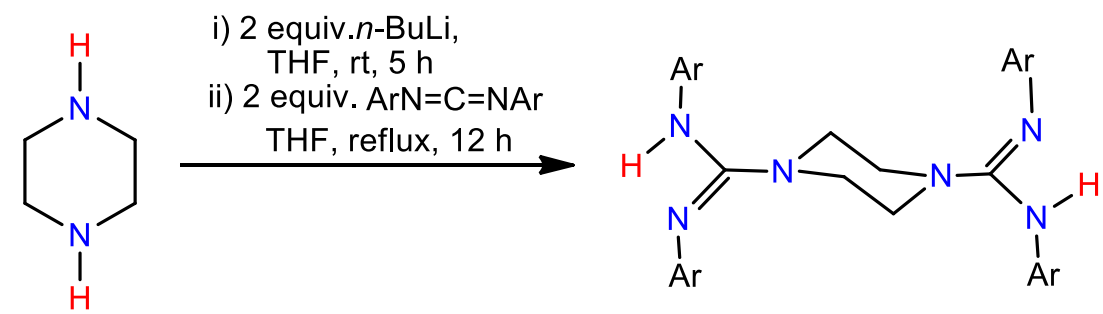

$\mathbf{L}^{1}(2 \mathrm{H}) ; \mathrm{Ar}=2,6-\mathrm{Me}_{2} \mathrm{C}_{6} \mathrm{H}_{3}$

$\mathrm{L}^{2}(2 \mathrm{H}) ; \mathrm{Ar}=2,6-{ }^{\mathrm{i}} \mathrm{Pr}_{2} \mathrm{C}_{6} \mathrm{H}_{3}$

$\mathrm{L}^{3}(2 \mathrm{H}) ; \mathrm{Ar}=2,4,6-\mathrm{Me}_{3} \mathrm{C}_{6} \mathrm{H}_{2}$

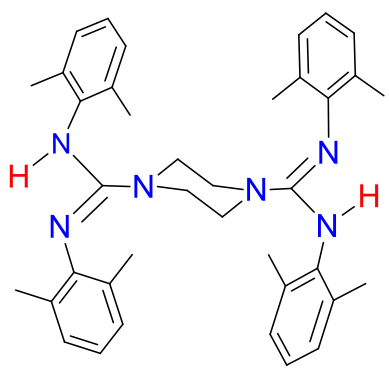

$\mathrm{L}^{1}(\mathbf{2 H})$

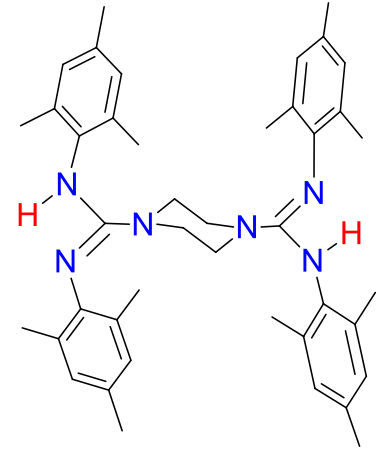

$\mathrm{L}^{2}(2 \mathrm{H})$

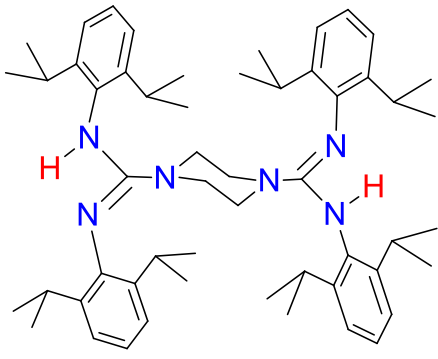

$L^{3}(2 H)$

Scheme 1. Synthesis of bridged bis-guanidine ligands.

$\mathrm{H}), 1.21(\mathrm{~d}, J=8.0 \mathrm{~Hz}, 24 \mathrm{H}), 2.42\left(\mathrm{~s}, 8 \mathrm{H},\left(\mathrm{N}\left(\mathrm{CH}_{2}\right)_{2} \mathrm{~N}\right)\right)$, 3.33-3.40 (sept, $8 \mathrm{H}$ ), 7.05 (d, $J=8.0 \mathrm{~Hz}, 8 \mathrm{H}$, ArH), 7.15$7.19(\mathrm{~m}, 4 \mathrm{H}, \mathrm{ArH}) .{ }^{13} \mathrm{C} \mathrm{NMR}\left(101 \mathrm{MHz}, \mathrm{CDCl}_{3}, 25^{\circ} \mathrm{C}\right)$ : $\delta 23.5,27.5,28.3,44.2\left(\mathrm{~N}\left(\mathrm{CH}_{2}\right)_{2} \mathrm{~N}\right), 124.3(\mathrm{ArC}), 127.4$ $(\mathrm{ArC}), 134.9(\mathrm{ArC}), 145.3(\mathrm{ArC}), 164.6\left(\mathrm{~N}_{3} C\right)$.

\section{Results and Discussion}

\subsection{Synthesis and spectroscopic characterization}

The bridged bis-guanidine molecules such as $\mathrm{L}^{1}(2 \mathrm{H})$, $\mathrm{L}^{2}(2 \mathrm{H})$ and $\mathrm{L}^{3}(2 \mathrm{H})$, where $\mathrm{L}=\left\{\operatorname{ArNCNAr}_{2}\{\mu\right.$ $\mathrm{N}\left(\mathrm{C}_{2} \mathrm{H}_{4}\right)_{2} \mathrm{~N}$, for $\mathrm{L}^{1}(2 \mathrm{H})\left(\mathrm{Ar}=2,6-\mathrm{Me}_{2}-\mathrm{C}_{6} \mathrm{H}_{3}\right), \mathrm{L}^{2}(2 \mathrm{H})$ $\left(\mathrm{Ar}=2,4,6-\mathrm{Me}_{3}-\mathrm{C}_{6} \mathrm{H}_{2}\right)$ and $\mathrm{L}^{3}(2 \mathrm{H})\left(\mathrm{Ar}=2,6-{ }^{i} \mathrm{Pr}_{2}\right.$ - $\left.\mathrm{C}_{6} \mathrm{H}_{3}\right)$, were prepared by previously reported literature procedures by using piperazine (or dilithiated piperazine) and $N, N^{\prime}$-diaryl carbodiimide as precursors (Scheme 1). ${ }^{24,25}$

$N, N^{\prime}$-diaryl carbodiimides are important starting materials for the synthesis of several nitrogen-donor ligands such as amidines, formamidines, mono- or biguanidines, $\mathrm{N}$-heterocyclic carbene-carbodiimide (NHC-CDI) adducts, etc. We have previously reported several bulky nitrogen-donor ligands such as 1,3-disubstituted formamidines, tetra-substituted guanidines, bis-guanidines, NHC-CDI adducts by using $N, N^{\prime}$-diaryl CDIs as precursors. ${ }^{29-31}$

Generally, three procedures allow the synthesis of guanidinates of aluminum metal complexes. ${ }^{7}$ i) Metallation of neutral guanidines with aluminum alkyls; ii) Salt metathesis reaction of alkali guanidinates with $\mathrm{AlX}_{3}(\mathrm{X}$ $=$ halide); iii) Addition of Al-N bond of $\mathrm{Al}_{2}\left(\mathrm{NMe}_{2}\right)_{6}$ to carbodiimide. ${ }^{12}$ By employing the first method, guanidinates of aluminum complexes were prepared. Metallation of neutral bis-guanidines with $\mathrm{AlR}_{3}(\mathrm{R}=$ alkyl) afforded the guanidinates of aluminum alkyl complexes. The less to more bulky bis-guanidine ligands $\mathrm{L}^{1-3}(2 \mathrm{H})$ have been utilized to prepare aluminum alkyl complexes (1-3). The synthesis of organoaluminum compounds $\mathbf{1}\left[\mathrm{L}^{1}\left(\mathrm{AlMe}_{2}\right)_{2}\right]$ and $\mathbf{2}\left[\mathrm{L}^{2}\left(\mathrm{AlMe}_{2}\right)_{2}\right]$ was achieved by the reaction of corresponding free ligand with trimethyl aluminum in toluene at room temperature (Scheme 2).

The treatment of $\mathrm{L}^{3}(2 \mathrm{H})$ with trimethylaluminum at elevated temeparature $\left(80{ }^{\circ} \mathrm{C}\right)$ in toluene resulted in compound 3 (Scheme 3 ). Considering the fact that ligated (monoanionic) aluminum dihalides are ideal precursors for isolation of low valent $\mathrm{Al}(\mathrm{I})$ heterocycles (NHC analogues), ${ }^{32}$ hence, we aimed to prepare 
<smiles>[Al]N=C(N[Al])N1CCN(C(=N[Al])N([Al])[Al])CC1</smiles>

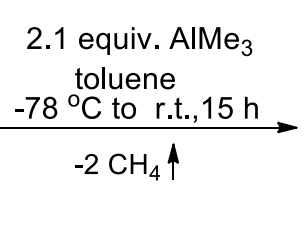<smiles></smiles>

(1) $\mathrm{Ar}=2,6-\mathrm{Me}_{2} \mathrm{C}_{6} \mathrm{H}_{3}$

(2) $\mathrm{Ar}=2,4,6-\mathrm{Me}_{3} \mathrm{C}_{6} \mathrm{H}_{2}$

Scheme 2. Synthesis of bimetallic aluminum alkyl complexes $\mathbf{1}$ and $\mathbf{2}$.<smiles>[Al]N=C(N=[Al])N1CCN(C(=N[Al])N([Al])[Al])CC1</smiles>

$\mathrm{Ar}=2,{ }^{-}{ }^{i} \mathrm{Pr}_{2} \mathrm{C}_{6} \mathrm{H}_{3}$

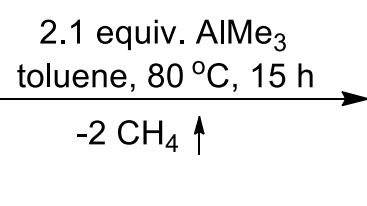

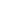<smiles></smiles>

(3) $\mathrm{Ar}=2,6-{ }^{i} \mathrm{Pr}_{2} \mathrm{C}_{6} \mathrm{H}_{3}$

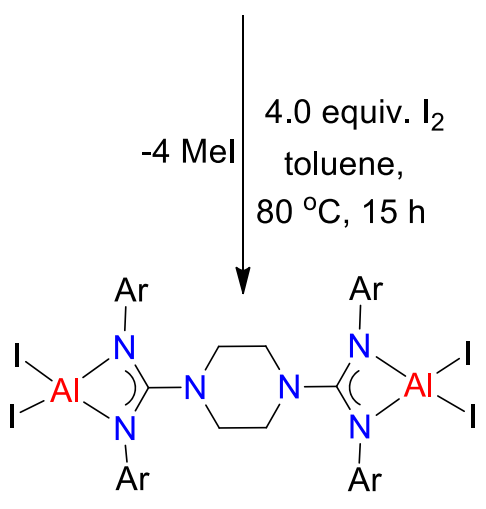

(4) $\mathrm{Ar}=2,6-{ }^{i} \mathrm{Pr}_{2} \mathrm{C}_{6} \mathrm{H}_{3}$

Scheme 3. Synthesis of bimetallic aluminum alkyl and iodide complexes $\mathbf{3}$ and $\mathbf{4}$.

$N, N^{\prime}$-chelated aluminum diiodide complex. This was achieved by alkyl-halide exchange reaction. Compound 4 was prepared from the reaction of $\mathbf{3}$ with molecular iodine in $\mathrm{C}_{6} \mathrm{D}_{6}$ at $80{ }^{\circ} \mathrm{C}$ for $15 \mathrm{~h}$. Compounds 1,2,3 and $\mathbf{4}$ were isolated as colorless crystalline solids in $62 \%, 60 \%, 59 \%$ and $70 \%$ yields, respectively. All the compounds were found to be thermally stable and melt in the range of $185-280{ }^{\circ} \mathrm{C}$. The metal complexes 1-4 were characterized by multinuclear $\left({ }^{1} \mathrm{H}\right.$ and ${ }^{13} \mathrm{C}$ ) magnetic resonance spectroscopy. Furthermore, structure of compounds $\mathbf{2 - 4}$ were confirmed by single crystal X-ray structural analysis. All the compounds 1-4 display the expected number of signals in the ${ }^{1} \mathrm{H}$ and ${ }^{13} \mathrm{C}$ NMR spectra and are consistent with their composition.

The ${ }^{1} \mathrm{H}$ NMR spectra of compounds $\mathbf{1}$ and $\mathbf{2}$ exhibit singlet resonances at -0.34 and $-0.31 \mathrm{ppm}$ in $\mathrm{C}_{6} \mathrm{D}_{6}$, respectively corresponding to 12 protons of the two
$\mathrm{AlMe}_{2}$ groups, i.e., $\mathrm{L}^{1-2}\left(\mathrm{AlMe}_{2}\right)_{2}$. Similarly, the ${ }^{1} \mathrm{H}$ spectrum of compound $\mathbf{3}$ shows a singlet resonance at $-0.73 \mathrm{ppm}$ in $\mathrm{CDCl}_{3}$ corresponding to 12 protons of the two $\mathrm{AlMe} e_{2}$ groups, i.e., $\mathrm{L}^{3}\left(\mathrm{AlMe}_{2}\right)_{2}$. In the ${ }^{1} \mathrm{H}$ spectrum, a complete disappearance of singlet resonance at $-0.73 \mathrm{ppm}$ in $\mathrm{CDCl}_{3}$, which indicates the formation of compound $4 .{ }^{13} \mathrm{C}$ NMR spectra of compounds $\mathbf{1 , 2 , 3}$ and $\mathbf{4}$ show a characteristic peak for the $\mathrm{N} 3 C$ carbon atom of the bis-guanidinate ligand 163.1, 163.2, 162.5 and 164.6 ppm (compound 1-2 in $\mathrm{C}_{6} \mathrm{D}_{6}$ while 3-4 in $\mathrm{CDCl}_{3}$ ) respectively. ${ }^{13} \mathrm{C}$ NMR spectra of compounds 1, $\mathbf{2}$ and $\mathbf{3}$ exhibit a characteristic peak for the $\mathrm{Al}\left(\mathrm{CH}_{3}\right)_{2}$ at $-9.2,-9.2$, and $-9.4 \mathrm{ppm}$ respectively, which is absent in the case of compound 4 . However, the presence of two iodide ligands which are attached to aluminum atom in compound $\mathbf{4}$ was further confirmed by single crystal X-ray structural analysis. 


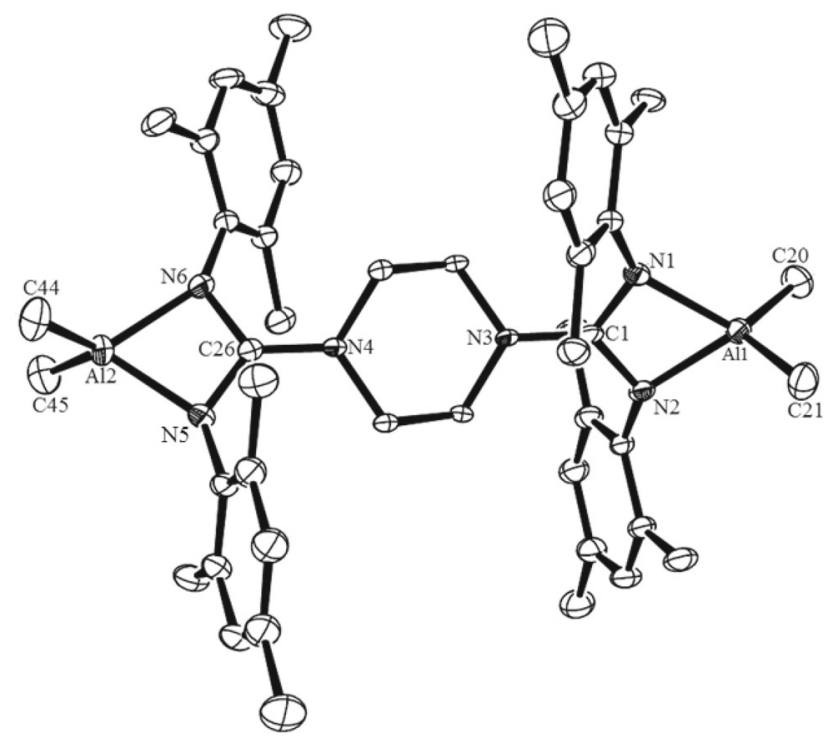

Figure 1. Molecular structure of 2. The thermal ellipsoids are shown at $30 \%$ probability, and all the hydrogen atoms are omitted for clarity. Selected bond distances $(\AA)$ and bond angles (deg): Al1-C20 1.949(6), Al1-C21 1.953(6), Al2-C45 1.925(7), Al2-C44 1.959(6), N1-Al1 1.933(4), N2-Al1 1.933(4), N1-Al1-N2 68.75(16), N1-Al1-C21 114.1(2), N2-A11-C21 115.9(2), N6-Al2-N5 69.15(17) N6-Al2-C44 115.0(3) N5-Al2C44 112.7(2), C45-Al2-N6 113.0(3), C45-Al2-C44 119.2(3).

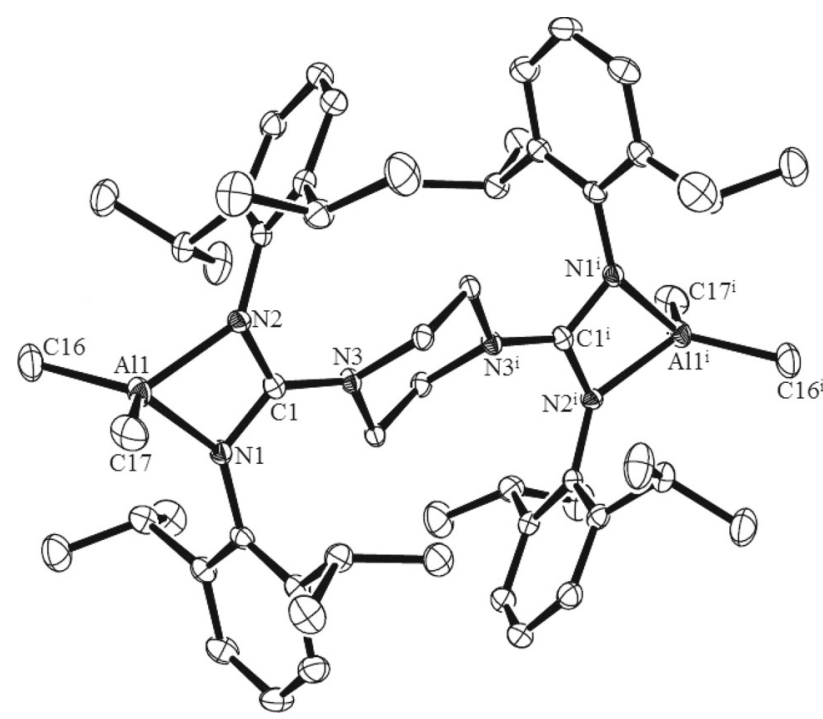

Figure 2. Molecular structure of 3. The thermal ellipsoids are shown at $30 \%$ probability, and all the hydrogen atoms are omitted for clarity. Selected bond distances $(\AA)$ and bond angles (deg): Al1-C16 1.962(3), Al1-C17 1.952(3), N1-Al1 1.941(3), N2-Al1 1.934(2), N1-C1 1.348(3), N2-C1 1.352(4). N2-A11-N1 69.39(10), N2-Al1-C17 114.38(13), N2-Al1-C16 118.66(12), C17-A11-C16 $115.24(15)$.

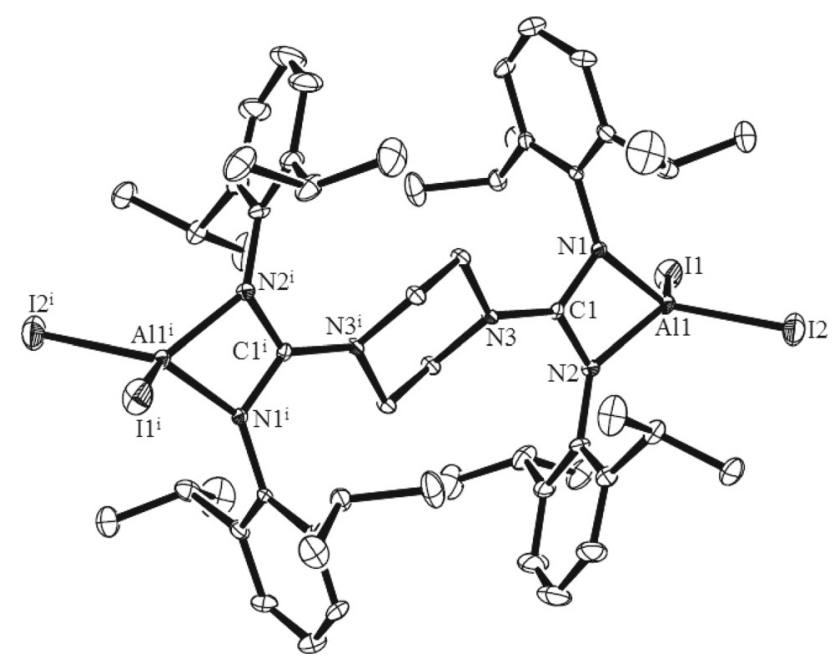

Figure 3. Molecular structure of 4. The thermal ellipsoids are shown at $30 \%$ probability, and all the hydrogen atoms are omitted for clarity. Selected bond distances $(\AA)$ and bond angles (deg): Al1-I1 2.477(2), Al1-I2 2.4555(18), N1-Al1 1.896(5), N2-Al1 1.886(5), N1-C1 1.347(7), N2-C1 1.363(7), N2-Al1-I2 118.07(16), N1-Al1-I1 116.64(16), N1-Al1-I2 121.37(17), I1-Al1-I2 108.28(6), N1-Al1-N2 71.2(19)

\subsection{Crystallographic information}

The crystals of 2-4 suitable for single crystal X-ray diffraction analysis were recrystallized from the concentrated toluene solution. The compound $\mathbf{2}$ crystallizes in triclinic system with $P \overline{1}$ space group, while, both compounds $\mathbf{3}$ and $\mathbf{4}$ crystallized in the monoclinic system with $P 2_{1} / n$ space group. Both compounds 2 and $\mathbf{3}$ are isostructural. Molecular structures of these complexes 2-4 are shown in Figures 1, 2 and 3, respectively. The crystal data and structure refinement details of complexes 2-4 are summarized in Table 1. Solid state structures of compounds $\mathbf{2}$ and $\mathbf{3}$ reveal that, each of the aluminum centers is coordinated by two carbon atoms from two alkyl groups, as well as two nitrogen atoms from the bis-guanidinate ligand in $N, N^{\prime}$-chelate fashion to form a distorted tetrahedral geometry. Similarly, in the case of compound $\mathbf{4}$, the aluminum center is in distorted tetrahedral geometry, which is surrounded by the nitrogen atoms of chelating bridged bis-guanidine and two iodine moieties. The Al-C bond lengths for the compounds 2 and 3 lie between 1.949(6) $\AA$ and 1.962(3) $\AA$, these values are similar to the reported values of $\mathrm{Al}-\mathrm{C}$ bond lengths. ${ }^{6-13}$ The Al-I bond distances in 4 Al1I1 is 2.507(2) $\AA$ and Al1-I2 is 2.521(2) $\AA$ which are well in agreement with the reported values. ${ }^{6-13}$ The bite angles of the bridged bis-guanidine ligands N1-Al1$\mathrm{N} 2$, which are $68.75(16), 69.33(10)$ and $71.19(19)^{\circ} 4$ for 2-4, respectively. 
Table 1. Crystallographic and structure refinement data for 2, 3 and 4 .

\begin{tabular}{|c|c|c|c|}
\hline & 2 & 3 & 4 \\
\hline Empirical formula & $\mathrm{C}_{46} \mathrm{H}_{64} \mathrm{Al}_{2} \mathrm{~N}_{6}$ & $\mathrm{C}_{58} \mathrm{H}_{88} \mathrm{Al}_{2} \mathrm{~N}_{6}$ & $\mathrm{C}_{54} \mathrm{H}_{76} \mathrm{~N}_{6} \mathrm{Al}_{2} \mathrm{I}_{4}$ \\
\hline Formula weight & 754.99 & 923.35 & 1370.83 \\
\hline Temperature $[\mathrm{K}]$ & $100(2)$ & $100(2)$ & $100(2)$ \\
\hline Wavelength $[\lambda]$ & 0.71073 & 0.71073 & 0.71073 \\
\hline Crystal system & Triclinic & Monoclinic & Monoclinic \\
\hline Space group & $P \overline{1}$ & $P 2_{1} / n$ & $P 2_{1} / n$ \\
\hline$a[\AA]$ & $12.1222(19)$ & $12.528(4)$ & $10.5278(12)$ \\
\hline$b[\AA]]$ & $12.893(2)$ & $14.416(6)$ & $20.575(2)$ \\
\hline$c[\AA]$ & $15.790(2)$ & $15.911(6)$ & $14.0056(16)$ \\
\hline$\alpha\left[^{\circ}\right]$ & $71.271(10)$ & 90 & 90 \\
\hline$\beta\left[^{\circ}\right]$ & $78.039(10)$ & $95.087(10)$ & $98.131(7)$ \\
\hline$\gamma\left[{ }^{\circ}\right]$ & $86.732(11)$ & 90 & 90 \\
\hline Volume $[\AA]^{3}$ & $2286.3(6)$ & $2862.2(19)$ & $3003.2(6)$ \\
\hline$Z$ & 2 & 2 & 2 \\
\hline Calculated density $\left[\mathrm{g} \mathrm{cm}^{-3}\right]$ & 1.097 & 1.071 & 1.516 \\
\hline$\mu(\operatorname{Mo~K} \alpha) / \mathrm{mm}^{-1}$ & 0.100 & 0.091 & 2.142 \\
\hline $\mathrm{F}(000)$ & 816.0 & 1008.5 & 1357.3 \\
\hline Theta range/ ${ }^{\circ}$ & $2.40-25.5$ & $2.44-25.5$ & $2.47-26.12$ \\
\hline Reflections collected & 26359 & 15753 & 25353 \\
\hline Independent reflections & 8485 & 5292 & 5893 \\
\hline GOOF on $\mathrm{F}^{2}$ & 1.096 & 0.995 & 0.986 \\
\hline $\mathrm{R}_{1} / \mathrm{wR}_{2}[\mathrm{I}>2 \sigma(\mathrm{I})]$ & $0.1039 / 0.2620$ & $0.0580 / 0.1181$ & $0.0618 / 0.1872$ \\
\hline $\mathrm{R}_{1} / \mathrm{wR}_{2}$ (all data) & $0.1651 / 0.3421$ & $0.1411 / 0.1503$ & $0.0829 / 0.1875$ \\
\hline Largest diff. peak/ hole $\left[\mathrm{e} . \AA^{-3}\right]$ & $0.95 /-0.64$ & $0.50 /-0.55$ & $2.42 /-2.23$ \\
\hline$R_{\text {int }}$ & 0.1017 & 0.1120 & 0.1022 \\
\hline Data/restraints/parameters & $8485 / 0 / 503$ & $5292 / 0 / 309$ & $5893 / 0 / 306$ \\
\hline
\end{tabular}

\section{Conclusions}

A series of new examples of dinuclear aluminum heterocycles is reported. Synthesis of aluminum alkyl complexes such as $\left[\mathrm{L}^{1}\left(\mathrm{AlMe}_{2}\right)_{2}\right](\mathbf{1}),\left[\mathrm{L}^{2}\left(\mathrm{AlMe}_{2}\right)_{2}\right](\mathbf{2})$ and $\left[\mathrm{L}^{3}\left(\mathrm{AlMe}_{2}\right)_{2}\right]$ (3) was achieved by the deprotonation of a corresponding free ligand upon treatment with two equivalents of $\mathrm{AlMe}_{3}$ in toluene. The compound $4\left[\mathrm{~L}^{3}\left(\mathrm{AlI}_{2}\right)_{2}\right]$ was prepared by the reaction of the compound 3 with four equivalents of molecular iodine in toluene at $80{ }^{\circ} \mathrm{C}$. Solid state structures for compounds 2-3 reveal that $\mathrm{Al}$ is four-coordinated by two nitrogen atoms from the guanidinate ligand and two methyl groups to adopt a distorted tetrahedral geometry. Similarly, in compound $\mathbf{4}$, aluminum centers adopt a distorted tetrahedral geometry, in which $\mathrm{Al}$ is fourcoordinated by two $\mathrm{N}$ atoms of the ligand and two iodine ligands. We presume that compounds 1-4 are ideal precursors for the preparation of four-membered aluminum cations and low-valent dinuclear aluminum(I) heterocycles. Currently, such studies are underway in our laboratory.

\section{Supporting Information (SI)}

Crystallographic data for the structural analyses of complexes 2-4 have been deposited with the Cambridge Crystallographic Data Centre bearing the CCDC Nos. 1833108, 1833109 and 1833110, respectively. Copies of this information are available on request free of charge from CCDC, Union Road, Cambridge, CB21EZ, UK (fax: +44-1223-336033: email:deposit@ccdc.ac.uk or http://www.ccdc.cam.ac. uk). ${ }^{1} \mathrm{H}$ and ${ }^{13} \mathrm{C}\left\{{ }^{1} \mathrm{H}\right\}$ NMR spectra for compounds $\mathbf{1 - 4}$ (PDF) are reported in Supplementary information which is available at www.ias.ac.in/chemsci.

\section{Acknowledgements}

The authors thank the National Institute of Science Education and Research (NISER), HBNI, Bhubaneswar for supporting this work. T. P and A. B. acknowledge University Grant Commission (UGC), Govt. of India for their fellowships.

\section{References}

1. Chandra G, Jenkins A D, Lappert M F and Srivastava R C 1970 Amido derivatives of metals and metalloids. X. Reactions of titanium(IV), zirconium(IV), and 
hafnium(IV) amides with unsaturated substrates, and some related experiments with amides of boron, silicon, germanium, and tin(IV) J. Chem. Soc. A 2550

2. Coles M P 2006 Application of neutral amidines and guanidines in coordination chemistry Dalton Trans. 985

3. Frank T Edelmann 2008 Advances in the Coordination Chemistry of Amidinate and Guanidinate Ligands $A d v$. Organometal Chem. 57183

4. Edelmann F T 2012 Lanthanide amidinates and guanidinates in catalysis and materials science: A continuing success story Chem. Soc. Rev. 417657

5. Jones C 2010 Bulky guanidinates for the stabilization of low oxidation state metallacycles Coord. Chem. Rev. 254 1273

6. Han H, Guo Z, Zhang S, Hua Y and Wei X 2017 Synthesis and crystal structures of guanidinatoaluminum complexes and catalytic study for MPV reduction Polyhedron 126214

7. Han H-F, Guo Z-Q, Zhang S-F, Li J and Wei XH 2016 Guanidinatoaluminum complexes: Synthesis, crystal structures and reactivities $R S C A d v$. 6 101437

8. Cole M L, Davies A J, Jones C, Junk P C, McKay A I and Stasch A 2015 Aluminum and indium complexes derived from guanidines, triazenes, and amidines Z. Anorg. Allg. Chem. 6412233

9. Barry S T 2013 Amidinates, guanidinates and iminopyrrolidinates: Understanding precursor thermolysis to design a better ligand Coord. Chem. Rev. 257 3192

10. Bonyhady S J, Collis D, Frenking G, Holzmann N, Jones C and Stasch A 2010 Synthesis of a stable adduct of dialane(4) $\left(\mathrm{Al}_{2} \mathrm{H}_{4}\right)$ via hydrogenation of a magnesium(I) dimer Nat. Chem. 2865

11. Kenney A P, Yap G P A, Richeson D S and Barry S T 2005 The insertion of carbodiimides into $\mathrm{Al}$ and $\mathrm{Ga}$ amido linkages. Guanidinates and mixed amido guanidinates of aluminum and gallium Inorg. Chem. 442926

12. Chang C-C, Hsiung C-S, Su H-L, Srinivas B, Chiang M Y, Lee G-H and Wang Y 1998 Carbodiimide insertion into organoaluminum compounds and thermal rearrangement of the products Organometallics 17 1595

13. Aeilts S L, Coles M P, Swenson D C, Jordan R F and Young V G, Jr. 1998 Aluminum alkyl complexes containing guanidinate ligands Organometallics 17 3265

14. Normand M, Roisnel T, Carpentier J F and Kirillov E 2013 Dinuclear vs. Mononuclear complexes: Accelerated, metal-dependent ring-opening polymerization of lactide Chem. Commun. 4911692

15. Li W, Ouyang H, Chen L, Yuan D, Zhang Y and Yao Y 2016 A comparative study on dinuclear and mononuclear aluminum methyl complexes bearing piperidylphenolato ligands in rop of epoxides Inorg. Chem. 55 6520

16. Chen L, Li W, Yuan D, Zhang Y, Shen Q and Yao Y 2015 Syntheses of mononuclear and dinuclear aluminum complexes stabilized by phenolato ligands and their applications in the polymerization of $\varepsilon$-caprolactone: A comparative study Inorg. Chem. 544699
17. Gavrilova A L and Bosnich B 2004 Principles of mononucleating and binucleating ligand design Chem. Rev. 104349

18. Li W, Ma X, Walawalkar M G, Yang Z and Roesky H W 2017 Soluble aluminum hydrides function as catalysts in deprotonation, insertion, and activation reactions Coord. Chem. Rev. 35014

19. Jakhar V K, Barman M K and Nembenna S 2016 Aluminum monohydride catalyzed selective hydroboration of carbonyl compounds Org. Lett. 184710

20. Bismuto A, Cowley M J and Thomas S P 2018 Aluminum-catalyzed hydroboration of alkenes ACS Catal. 82001

21. Nikonov G I 2017 New tricks for an old dog: Aluminum compounds as catalysts in reduction chemistry ACS Catal. 77257

22. Sharma M K, Sinhababu S, Mukherjee G, Rajaraman G and Nagendran S 2017 A cationic aluminum complex: An efficient mononuclear main-group catalyst for the cyanosilylation of carbonyl compounds Dalton Trans. 467672

23. Prashanth B, Bhandari M, Ravi S, Shamasundar K R and Singh S 2018 Electronically unsaturated threecoordinate aluminum hydride and organoaluminum cations Chem. Eur. J. 244794

24. Baishya A, Peddarao T, Barman M K and Nembenna S 2015 Catalyst free $\mathrm{C}-\mathrm{N}$ bond formation by the reaction of amines with diimides: Bulky guanidines New J. Chem. 397503

25. Jin G, Jones C, Junk P C, Lippert K-A, Rose R P and Stasch A 2009 Synthesis and characterisation of bulky guanidines and phosphaguanidines: Precursors for low oxidation state metallacycles New J. Chem. 3364

26. Dolomanov O V, Bourhis L J, Gildea R J, Howard J A $\mathrm{K}$ and Puschmann H 2009 Olex2: A complete structure solution, refinement and analysis program J. Appl. Crystallogr. 42339

27. Sheldrick G M 2015 Shelxt - integrated space-group and crystal-structure determination Acta Crystallogr. Sect. A 713

28. Sheldrick G M 2008 A short history of shelx Acta Crystallogr. Sect. A 64112

29. Baishya A, Kumar L, Barman M K, Peddarao T and Nembenna S 2016 Air stable N-heterocyclic carbenecarbodiimide ("NHC-CDI") adducts: Zwitterionic type bulky amidinates ChemistrySelect 1498

30. Peddarao T, Baishya A, Barman M K, Kumar A and Nembenna S 2016 Metal-free access of bulky $N, N^{\prime}$ diarylcarbodiimides and their reduction: Bulky $N, N^{\prime}$ diarylformamidines New J. Chem. 407627

31. Baishya A, Kumar L, Barman M K, Biswal H S and Nembenna S 2017 N-heterocyclic carbenecarbodiimide ("NHC-CDI") adduct or zwitterionic-type neutral amidinate-supported magnesium(II) and zinc(II) complexes Inorg. Chem. 569535

32. Cui C, Roesky H W, Schmidt H-G, Noltemeyer M, Hao H and Cimpoesu F 2000 Synthesis and structure of a monomeric aluminum(I) compound $\left[\left\{\mathrm{HC}(\mathrm{CMeNAr})_{2}\right\} \mathrm{Al}\right]\left(\mathrm{Ar}=2,6-{ }^{i} \mathrm{Pr}_{2} \mathrm{C}_{6} \mathrm{H}_{3}\right):$ A stable aluminum analogue of a carbene Angew. Chem. Int. Ed. 394274 